\title{
Die ekonomiese impak van belasting op mynwater in Suid-Afrika
}

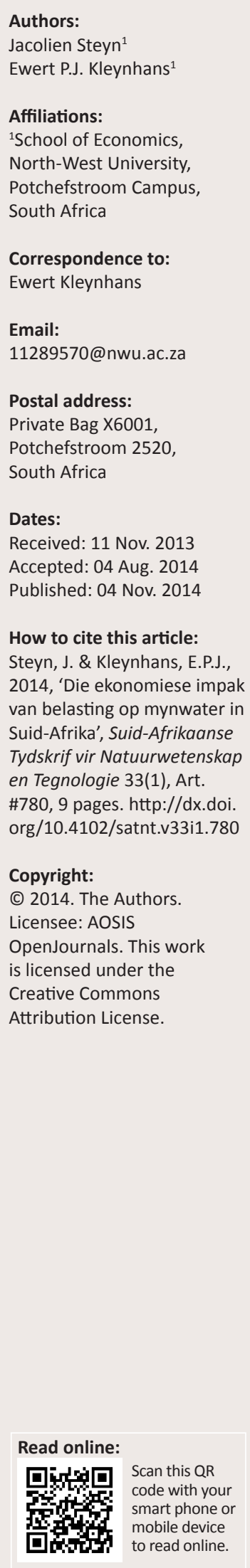

Waterbesoedeling deur myne is 'n groot probleem in Suid-Afrika. Hierdie studie ondersoek die bydrae wat ' $n$ bykomende belasting op die mynwese kan lewer. In die verlede is aandag aan die stygende vraag na waterhulpbronne deur middel van aanbodkantmeganismes gegee. Myne is die grootste besoedelaar van drinkwater in Suid-Afrika en die vraag is of dit steeds die aangewese manier is om die probleem te probeer oplos. Hierdie studie stel voor dat die owerheid eerder 'n bykomende belasting op myne behoort te hef en ondersoek dan wat die uitwerking daarvan op die vraag na water sal wees, sowel as op besoedeling, en watter effek dit op die land se ekonomie, die onderskeie nywerheidsektore en verbruikers sal hê, en in besonder op die heel armes van die bevolking. Dié navorsing het gevorderde ekonomies algemene ewewigsmodellering gebruik om die probleem empiries te ondersoek. Die resultate van die model is beduidend vir die scenario's wat bestudeer is, beide op die kort en die lang termyn. Daar is bevind dat 'n bykomende belastingheffing op die verbruik van water deur myne wel die gewenste resultate sal lewer, met min negatiewe gevolge vir die bedryf en die land as geheel.

The economic impact of taxation on mine water in South Africa. Water pollution by mines is a major problem in South Africa. This study examined the contribution that an additional tax on the consumption of water by the mining industry can provide. In the past, the rising demand for water resources was addressed through supply-side mechanisms. Mines are the biggest polluter of drinking water in South Africa and the question is whether this is still the most appropriate way to address the problem. This study proposes that the authorities should consider an additional tax on mines and investigates the effect it will have on the demand for water, as well as its pollution, and the effect on the country's economy, various industrial sectors and consumers, and in particular the poorest citizens. The research applied advanced economic general equilibrium modelling in its empirical investigation. The results of the modelling are significant both in the short- and long-term scenarios studied. It was found that an additional tax on the consumption of water by mines will produce the desired results, with little negative consequences for the industry and the country as a whole.

\section{Inleiding}

There is water within us, let there be water with us. Water never rests. When flowing above, it causes rain and dew. When flowing below it forms streams and rivers. If a way is made for it, it flows along that path. And we want to make that path. We want the water of this country to flow out into a network reaching every individual - saying: here is this water, for you. Take it; cherish it as affirming your human dignity; nourish your humanity. With water we will wash away the past, we will from now on ever be bounded by the blessing of water. Antjie Krog (Department of Water Affairs and Forestry [DWARF] 1997:1)

Die verbruik, besoedeling en behandeling van water deur die mynwese in Suid-Afrika is 'n groot probleem. Hierdie studie wil oplossings vir die probleem ondersoek, deur van gevorderde, ekonomies algemene ewewigsmodellering in 'n empiriese analise gebruik te maak. Myne is die grootste besoedelaar van drinkwater in Suid-Afrika. In die verlede is aanbodkantmeganismes gebruik om die stygende vraag na water te bestuur (Smakhtin et al. 2001), maar dit is nie noodwendig die enigste wyse nie. Dié studie ondersoek die uitwerking wat bykomende belasting op myne se verbruik van water sal hê.

Die agtergrond van die probleem gaan eerstens geskets word. Daarna word aandag geskenk aan die wetlike aspekte rakende water en die besoedeling deur myne. Dan word die metodologie verduidelik rondom algemene ewewigsmodulering en hoe die model spesifiek vir hierdie studie aangepas is, gevolg deur die verslag van die empiriese bevindinge van die analise. Beide korten langtermynsimulasies is gedoen, wat die direkte en indirekte effek van bykomende belasting op myne, asook nywerheidsektore en verbruikers ondersoek het, en in besonder die impak op die heel armstes van die bevolking. 
Daar bestaan ' $n$ toenemende behoefte om beleid in plek te hê wat volhoubare verskaffing uit waterbronne sal waarborg en verseker dat die beleid uitgevoer word. Die SuidAfrikaanse Departement van Omgewingsake en Toerisme (Department of Environmental Affairs and Tourism [DEAT] 1999) definieer water as: '... an indispensable natural resource, fundamental to life, the environment, food production, hygiene and sanitation, and industry and power generation.' Water is ' $n$ noodsaaklike hulpbron en behoort daarom uiters konserwatief gebruik en bestuur te word. Water kan wel hergebruik word, maar is nie geheel en al hernubaar nie. Water is nodig vir oorlewing en die voorsiening in die mens se basiese behoeftes, asook vir produksie en die generering van inkome. Navorsing deur die Plus Economic Group (2010) het bevind dat waterprobleme nie net die mynwese se produksie benadeel nie, maar die land se ekonomie in geheel, asook die per capita-inkome van elke landsburger verlaag.

Die debat oor water is nie nuut nie. Dispute oor water het reeds 3000 VC bestaan (Adler et al. 2007), maar die wyse waarmee mense dit benader, het vandag wel verander. Die belangrikste kwessies in die twintigste eeu is of die beskikbare waterbronne steeds bruikbaar en die kwaliteit daarvan aanvaarbaar is. Hierdie studie fokus spesifiek op die mynbousektor van Suid-Afrika, hoe hulle die beskikbare waterbronne besoedel en hoe die probleem deur die heffing van bykomende belasting gehanteer kan word.

Die dreinering van suurwater deur myne bedreig die land se waterbronne (Ochieng, Seanego \& Nkwonta 2010:3352). Suurwater kontamineer die water wat omliggende woongebiede daagliks gebruik. Wanneer hierdie besoedelde water op die lang termyn gebruik word, wat dikwels tot 40 jaar kan wees, kan dit tot gevaarlike siektes aanleiding gee. Dit bedreig nie net die gesondheid van mense nie, maar ook van gesaaides wat weer Suid-Afrika se voedselsekuriteit kan bedreig. Tans word watersekuriteit meestal deur dreineringswater bedreig (Taylor 2010:2). Water wat deur die grond dreineer, kom veral voor by uitgediende gouden steenkoolmyne, wat nie gerehabiliteer is nadat hulle gesluit is nie. Dit gebeur veral in Gauteng en Mpumalanga (McDermott 2012) en is 'n baie duur probleem. Die TransCaledon Tonnelowerheid is verantwoordelik daarvoor om Gauteng se water skoon te hou en bestee ongeveer R900 miljoen aan skoonmaakprosedures (Trans-Caledon Tunnel Authority [CTA] 2007), en dít net op die kort termyn.

Sowat 70\% van die drinkwater wat in stedelike en landelike gebiede gebruik word, is afkomstig van damme, mere en fonteine. Navorsing op die water van Johannesburg se myngebiede deur Naicker, Cukrowka en McCarthy (2003), het bevind dat die grondwatertafel verhoogde konsentrasies van swaarmetale bevat. Hierdie watertafel, waarvandaan gemeenskappe hul water $\mathrm{kry}$, is na aan die oppervlak geleë. Naicker et al. (2003) beweer dat die besoedelde water in strome en riviere invloei en vir tot $20 \%$ van die totale watervloei verantwoordelik is, wat uiteindelik die suurgehalte van die water aansienlik verhoog.
Navorsing deur Tempelhoff en Van der Walt (2012) toon aan dat plaasboere in die Delmas-omgewing, Mpumalanga, reeds probleme ondervind en dringend na oplossings soek. Hulle beweer dat afvalwater daagliks deur myne in die omliggende riviere gepomp word, veral deur goudmyne. Dit is dié waterbronne wat deur die boere vir besproeiing gebruik word. Plaaslike gemeenskappe in dié besoedelde distrikte verwag dat die regering iets aan die probleem behoort te doen en oplossings moet vind.

Die wet vereis dat myne wat waterbronne benut, waterlisensies moet hê. Tempelhoff (2012) het egter bevind dat slegs 72 van die myne tussen Januarie 2011 en Maart 2012 die nodige permitte gehad het, terwyl 53 hul aktiwiteite onwettig bedryf het. Die probleem is dus, soos in die meeste minder ontwikkelde lande, dat daar wel wette en regulasies bestaan, maar dat hulle nie behoorlik gemoniteer en afgedwing word nie (Kleynhans \& Kotze 2008:264). Die volgende afdeling gee meer aandag aan die wetlike aspekte rondom die kwessie.

\section{Wetlike aspekte rakende water}

Die beleid en regulasies oor watergebruik is voor 1994 hoofsaaklik geskoei op die modelle van voormalige Europese koloniale moondhede. 'n Verslag deur die Waternavorsingskommissie (2004) het aangetoon dat beleid wat watergebruik sedert 1875 gereguleer het, hoofsaaklik verskillende Europese benaderings nagevolg het en slegs tydens periodes van groot droogtes gewysig is. Sedertdien het die Departement van Waterwese verskeie Witskrifte gepubliseer, wat beskryf het hoe toekomstige beleid daar sou uitsien en hoe dit geïmplementeer gaan word. 'n Verslag oor waterbeleid in Suid-Afrika (DWARF 1997), wat reeds gedurende 1994 verskyn het, het aangetoon dat die land ' $n$ besondere behoefte aan 'n nuwe en demokratiese, nasionale beleid het; een wat die wet op water sal rig en die gebruik van water- en prysstrukture insluit. Die kabinet het daarop voortgebou, nuwe wetgewing ontwerp en beleid begin implementeer (DWARF 1997). Dit het van die sleutelvoorstelle ingesluit, soos byvoorbeeld dat alle water in Suid-Afrika voortaan as gemeenskaplike nasionale hulpbronne beskou sal word; dat alle water volgens spesifieke doelstellings en riglyne gehanteer sal word; en dat diegene wat riviere en ander waterbronne benut, 'n bestuursheffing daarop sal betaal om die koste te dra. Op die lang termyn sal hierdie maatreëls alle bedrywe raak wat water in hul produksieprosesse gebruik.

Na die 1996-verslag publiseer die Departement van Waterwese gedurende 1999 'n finale verslag, wat ook prysstrukture ingesluit het (DWARF 1999). Dié verslag het benadruk dat die grootste probleem 'n gebrek aan waterlisensies was. Die Departement sien waterlisensies as 'n belangrike instrument in die beheer en bestuur van beskikbare waterbronne, om te verseker dat water regverdig tussen gebruikers versprei sal word en ook te waak teen oorbenutting, beskadiging en besoedeling (DWARF 2008). Registrasie deur verbruikers sou vrywillig plaasvind, 
waarna verbruikers ooreenkomstig die volumes wat hulle verbruik, sal betaal.

\section{Waterbesoedeling deur myne}

Myne wat sonder die nodige waterlisensie opereer, en myne wat eers met produksie begin en daarna aansoek doen om die nodige lisensies en permitte, is tans die grootste probleem. In 2012 berig Janeke (2012:78) dat daar steeds 53 myne is wat onwettig sonder die nodige lisensies bedryf word, wat in ooreenstemming is met die bevindinge van Tempelhoff (2012). Alhoewel al die beleidsvoorstelle geïmplementeer is, het dit nie die besoedeling van die land se waterbronne verhoed nie. Dit het ook die debat oor die kwaliteit en beskikbaarheid van water in Suid-Afrika gekompliseer. Volgens die Plus Economics Group (2010) is suurwaterdreinering deur myne uiters skadelik, terwyl belanghebbendes dit ignoreer. Die suur wat in drinkwater gevind word, is reeds beduidend, terwyl die nodige stappe om mense daarteen te beskerm, nie gedoen word nie (Hobbs 2010).

'n Ondersoek na die afhanklikheid en gebruik van water deur die mynboubedryf in hul produksieprosesse, is gevolglik noodsaaklik. Die goudstormloop het reeds in 1886 naby Johannesburg begin (Hammel et al. 2000). Dit het vinnig tot die tegnologiese ontwikkeling van ander nywerhede gelei, werksgeleenthede geskep en meer mense laat verstedelik, wat almal op hul beurt weer meer water nodig het. Ontwikkeling het verdere stimulus aan die mynboubedryf verskaf, totdat dit gegroei het tot die grootte wat dit vandag is. Teen 2013 is die belangrikste leiers in die mynbedryf maatskappye soos Kumba Resources, Anglo Platinum, Anglo American, De Beers, Gold Fields, Exxaro en Harmony Gold (PricewaterhouseCoopers [PWC] 2011).

Myne is afhanklik van water en gebruik dit tydens produksie. Dit word gebruik om erts te ontgin en produkte te was. Wanneer die ontginningsprosesse voltooi is, moet daar van die water ontslae geraak word, en dit is waar die probleem van suurwater dan begin. Die vuil water vind uiteindelik 'n weg terug na die land se damme, riviere en spruite. Die uitwerking kan tot tien kilometer vanaf die punt van besoedeling bespeur word (Oelofse 2008). Gesien in die lig van die feit dat myne ooglopend nie gehoor gee aan die huidige owerheidsbeleid nie, kan die vraag gevra word of dit nie nodig geword het om bykomende belastings op myne te hef nie. Die geld kan gebruik word om water te suiwer en besoedeling op te klaar.

Wêreldwyd huldig ekonome uiteenlopende menings oor die heffing van besoedelingsbelastings op myne wat water besoedel. Volgens Boyd (2003) het Frankryk reeds so vroeg soos die 1960's sodanige belastings op myne ingestel en Duitsland in 1976. Boyd bevind egter dat die heffings nie eens die helfte so groot is as die meetbare maatskaplike skade wat die besoedeling veroorsaak nie. Alhoewel suksesstories oor belasting op water beperk is, wil dit voorkom asof dit wel met sukses in Duitsland geïmplementeer word. In Duitsland word myne beide op die direkte en indirekte gebruik van waterhulpbronne belas. Hul sukses word daaraan toegeskryf dat die tariewe besonder hoog is, dit met tyd toegeneem het en dat myne verantwoordelik gehou word vir veranderinge in die kwaliteit van die water.

Voordat Suid-Afrika blindelings Duitsland se voorbeeld volg en myne op hul gebruik en besoedeling van waterbronne belas, is deeglike navorsing egter noodsaaklik. Hierdie studie het daarom gevorderde ekonomies algemene ewewigsmodellering gebruik om die gevolge te ondersoek wat sulke belastings op die myne, sowel as op die totale ekonomie van Suid-Afrika moontlik kan inhou. Die volgende afdeling verduidelik die empiriese analise wat onderneem is.

\section{Algemene ewewigsmodellering}

In die empiriese analise van hierdie studie is ekonomies algemene ewewigsmodellering gebruik. Dit is aangepas om simulasies van belasting op water te kon akkommodeer. Die University of Pretoria General Equilibrium (UPGEM)-model wat deur die Universiteit van Pretoria, in samewerking met Monash Universiteit in Australië ontwikkel is (Cameron \& Naudé 2008), is in die studie gebruik. Die databasis is onttrek uit die Sosiale Rekenkundige Matriks (SAM) wat deur Statistiek Suid-Afrika gepubliseer is en dit is aangepas volgens die omvattende en gedetailleerde watersaldo wat die Wetenskaplike en Nywerheidnavorsingsraad (WNNR) in daardie jaar gepubliseer het (Council for Scientific and Industrial Research [CSIR] 2001).

Algemene ewewigsmodellering (of Computable General Equilibrium Models - CGE in Engels) is 'n wiskundige model wat die hele land se ekonomie voorstel. Dit sluit 32 nywerheids- en dienstesektore, huishoudings uit twaalf inkomegroepe, vier etniese groepe en verskillende woongebiede in (Horridge et al., 2000). Dit toon die skakeling tussen verskillende sektore en rolspelers in die ekonomie aan, sodat dit 'n rimpelende uitwerking reg deur die ekonomie kan simuleer, wanneer daar 'n ekonomiese verandering (skok) voorkom (Miller \& Blair 2009:681). Dit bevat vraag-, inkome- en produksiestrukture, bestaan uit duisende vergelykings en dui ook die terugspoel-effekte in die ekonomie aan (Dervis \& De Melo 1985:132; Van Heerden, Blignaut en Horridge 2007:108).

Die algemene ewewigsmodel moes egter aangepas word om voorsiening te maak vir water. 'n Soortgelyke studie is gedurende 2007 deur Van Heerden et al. (2007) onderneem, wat die gebruik van water deur bosbou en besproeiingsgewasse ondersoek het. Die huidige studie het grootliks hul metodologie nagevolg en hulle model gebruik. Daar is van Van Heerden et al. (2007) se model en data gebruik gemaak, wat oorspronklik op die SAM van 2001 gebaseer was. Ons het dit aangevul met die nuutste 2013-data van Statistiek Suid-Afrika. Hulle model bevat besondere detail wat in ons studie nodig is en wat nuwer modelle nie bevat nie. Dit was ook as onnodig en riskant 
beskou om 'n nuwe model te bou, aangesien min navorsers oor die kundigheid beskik om so 'n model van voor af op te stel. Die 2001-model van Van Heerden et al. (2007) het dus die instrumente voorsien wat ons gebruik het en waarop ons nuwe data ingevoer het.

Die model is gewysig om voorsiening te maak vir die groei in die vraag na water soos wat die getal verbruikers toeneem, vanweë ekonomiese vooruitgang en bevolkingsgroei. Verder staan die belastinginkome op water proporsioneel tot die hoeveelheid water wat verbruik word, en kan nywerhede die koste van water grootliks afwentel na verbruikers.

Die model aanvaar dat elke produksieproses produkte van ander bedrywe benut. Water is normaalweg gratis beskikbaar; behalwe vir spesifiek vasgestelde tariewe. Die hoeveelheid water wat aangebied word, word egter deur die owerheid en die weer bepaal. Anders as by ander verbruikersgoedere, bestaan daar normaalweg nie ' $n$ mark vir rou water nie. Daar word dan ook nie 'n markprys daaraan toegeken nie. Produsente kan ook nie op die kort termyn besluit hoeveel water hulle vir spesifieke prosesse benodig of dit verander nie.

Die huidige studie het beide die kort en lang termyn ondersoek. Verskeie scenario's is deur die model gesimuleer om die uitkomste van verskillende beleidsopsies te bestudeer en die resultate word hieronder bespreek. Sommige veranderlikes is op die kort termyn konstant, terwyl die meeste veranderliks op die lange duur wel kan verander. Enige periode langer as twee jaar is vir die doel van hierdie studie as die langer termyn beskou. Tydens die simulasies wat op die kort termyn gerig is, is aanvaar dat die kapitaalvoorraad van die onderskeie nywerhede konstant bly. Twee jaar is as lank genoeg beskou om nuwe investeringsbesluite te laat deurwerk en voorsiening vir die hertoewysing van kapitaalvoorraad tussen nywerhede te maak (Volkwyn \& Kleynhans 2014:5).

Soortgelyke simulasies is ook op die arbeidsmark uitgevoer. Die arbeidsmark word in elf verskillende groepe verdeel en word dan verder verdeel tussen geskoolde en ongeskoolde werkers. Daar is aangeneem dat die beskikbaarheid van ongeskoolde werkers op die kort termyn volmaak veranderlik (elasties) is, en wel teen 'n vasgestelde nabelastingkoers. Die aanbod van ongeskoolde werkers is egter onveranderlik op die lang termyn, terwyl die aanbod van geskoolde werkers beide op die kort en lang termyn beperk is.

Verdere aannames van die model is gegrond op teorie en praktyk en behels die volgende: Op nasionale vlak is investering op die lang termyn konstant en verwant aan die land se kapitaalvoorraad. Op die kort termyn is owerheidsbesteding ook 'n vaste item, maar op die lang termyn volg dit die tendense van huishoudelike verbruik na. Op die kort termyn is voorrade konstant, maar op die lang termyn volg dit nywerheidsuitsette na. Die gemiddelde huishoudelike verbruik volg veranderinge in looninkome op die kort termyn, terwyl dit op die langer termyn by vaste verhoudings kan aanpas. Totale verbruik van die onderskeie huishoudings en etniese groepe volg elk hul onderskeie aandeel in die nabelaste looninkome na. Die land se totale verbruik in elk van dié sektore is egter konstant. Dit vind plaas terwyl uitvoerders 'n konstante sensitiwiteit (elastisiteit) vanaf die internasionale markte ervaar. Daar word aanvaar dat invoere na gelang van plaaslike verbruik groei, met die relatiewe plaaslike of internasionale prysverhoudings as beperking.

Daar word algemeen aanvaar dat myne water dikwels vermors omdat dit goedkoop is. 'n Addisionele belastingheffing behoort dit te beperk. ' $n$ Verhoging in die prys van water kan myne miskien noodsaak om minder water te gebruik. Die waterintensiteit, gemeet as die water/ uitset-verhouding behoort dan te daal (Van Heerden et al. 2007:110). Die daling in waterverbruik kan dalk tot ' $n$ daling in mynbouproduksie lei, en/of myne noodsaak om ander insette te verhoog ten einde bestaande produksievlakke te handhaaf. Beter tegnologie kan daartoe lei dat minder water nodig is en dat dié wat wel verbruik word, meer effektief aangewend sal word. Hersirkulasie en suiwering van dieselfde water kan ook ekologiese voordele inhou. Hoe duurder water is, hoe meer ekonomies sal dit wees om in beter tegnologie te belê. 'n Bykomende substitusieterm is in die model ingebou om voorsiening te maak vir die verhoging in die vraag na kapitaalgoedere, byvoorbeeld nuwe tegnologie, vanweë die verandering in die prys van water. Op die vrye mark is die aanname dat ondernemings, soos myne, hul koste sal minimeer, en dan sal substitusie teen die grenswaardes kosteloos wees. Myne se besparing op waterbelasting, omdat hulle minder water gebruik, word dan gebalanseer deur die verhoogde besteding aan nuwe kapitaalgoedere.

Data vir hierdie studie is verkry uit die SAM wat deur Statistiek Suid-Afrika (2002) gepubliseer is, asook laasgenoemde se 2013-databasis. Dit is die nuutste beskikbare databasis wat geskik was vir die beoogde studie. Dit verteenwoordig bestaande verhoudings tussen die verskillende ekonomiese aanwysers en bied die geleentheid om inligting in baie detail daar te stel. Huishoudings is in twaalf inkomegroepe en vier etniese groepe verdeel. Daar is onderskei tussen noodsaaklike goedere en luukshede, terwyl die onderskeid tussen huishoudings se keuses vir plaaslik vervaardigde goedere en invoere ook in ag geneem is. Die model onderskei verder tussen 39 ekonomiese sektore, wat ook die mynwese insluit. Die mynboubedryf is voorts verdeel in steenkool, goud, ru-olie, petroleum en gas, asook ander mynbou.

Bykomende data was nodig om die model aan te pas om die effek van water op die ekonomie te moduleer. Om die gewysigde watervektore op die model toe te pas, is hulle by die konvensionele databasis gevoeg. Die som van die totale belasbare waterverbruik in die land en die onderskeie mynboubedrywe is min of meer gelyk aan die volume rou water in al die riviere en damme, asook reënwater. Die 
hoeveelheid water wat verbruik word, word in kolom 2 van Tabel 1 aangedui, terwyl kolom 1 die onderskeie mynbousektore met ' $\mathrm{n}$ ' $\mathrm{M}$ ' aandui. Daarvolgens kan gesien word dat besproeiing die grootste watergebruiker is, terwyl die mynbousektor jaarliks net meer as 453 miljoen kubieke meter water verbruik. Kolom 3 dui die onderskeie elastisiteit aan. Dit weerspieël die proporsionele verbruik van water relatief tot die proporsionele verandering in die grenskoste van water - met ander woorde, die gevoeligheid van verbruikers vir die verandering in die prys van water.

Die sensitiwiteit en betroubaarheid van die algemene ewewigsmodel is verder geskat deur verskillende grade

TABEL 1: Gemiddelde jaarlikse waterverbruik en die elastisiteit van die vraag na water.

\begin{tabular}{|c|c|c|}
\hline Vraag na water & $\begin{array}{l}\text { Belasbare water } \\
\left(\text { miljoen } \mathrm{m}^{3}\right)\end{array}$ & Elastisiteit \\
\hline Velde onder besproeiing & 8006.9 & -0.25 \\
\hline Droë velde & 0 & -0.15 \\
\hline Tuinbou onder besproeiing & 3815.2 & -0.25 \\
\hline Droë tuinbou & 0 & -0.15 \\
\hline Lewende hawe & 539.1 & -0.15 \\
\hline Bosbou & 1673 & n.a. \\
\hline Ander landbou & 0.8 & -0.15 \\
\hline Steenkool (M) & 26.3 & -0.32 \\
\hline Goud (M) & 185.9 & -0.32 \\
\hline Ru-olie, petroleum en gas (M) & 0.5 & -0.48 \\
\hline Ander mynbou (M) & 240.4 & -0.32 \\
\hline Voedsel en drank & 147.4 & -0.39 \\
\hline Tekstiel & 40.9 & -0.33 \\
\hline Skoeisel & 3.6 & -0.33 \\
\hline Chemikalieë en rubber & 54.7 & -0.15 \\
\hline Petroleum-raffinering & 84.8 & -0.48 \\
\hline Ander nie-metaalhoudende minerale & 40.5 & -0.32 \\
\hline Yster en staal & 51.7 & -0.27 \\
\hline Nie-ysterdraende metale & 12.9 & -0.27 \\
\hline Ander metaalprodukte & 55.2 & -0.27 \\
\hline Masjinerie: Ander & 14.6 & -0.25 \\
\hline Elektriese masjiene & 2.4 & -0.38 \\
\hline Radio & 1.1 & -0.38 \\
\hline Vervoertoerusting & 8 & -0.38 \\
\hline Hout, papier en pulp & 145.1 & -0.59 \\
\hline Ander vervaardiging & 5.1 & -0.38 \\
\hline Elektrisiteit & 237 & -0.8 \\
\hline Water & 0 & -0.6 \\
\hline Konstruksie & 42 & -0.38 \\
\hline Handel & 176 & -0.19 \\
\hline Hotelle & 27.7 & -0.19 \\
\hline Vervoerdienste & 94.6 & -0.19 \\
\hline Gemeenskapsdienste & 33.4 & -0.19 \\
\hline Finansiële dienste & 52.5 & -0.19 \\
\hline Eiendom & 123.6 & -0.19 \\
\hline Handel & 4.9 & -0.19 \\
\hline Algemene owerheid & 120.8 & -0.19 \\
\hline Gesondheidsdienste & 76.2 & -0.19 \\
\hline Ander dienste & 17.3 & -0.19 \\
\hline + huishoudelike gebruik & 2013 & - \\
\hline + ander gebruike & 5368 & - \\
\hline minus bosbou & -1673 & - \\
\hline Totaal & 21870.1 & - \\
\hline
\end{tabular}

Bron: Watertariefdata: Eie beramings van die outeurs gebaseer op verskeie ongepubliseerde databronne van die Departement van Waterwese en Bosbou, waterrade en munisipaliteite (per jaar). Elastisiteit: DBSA (2000); Renzetti (1992); Veck en Bill (2000); Le Maitre, Versveld en Chapman (2000)

$\mathrm{M}$, mynbousektore. van gevoeligheid (elastisiteit) tussen die onderskeie sektore te gebruik. 'n Belastingsimulasie van tien sent per kubieke meter is eerstens gebruik om die elastisiteit (hul reaksie, asook die verband tussen hulle) tussen verskillende bedrywe te skat. Daar is ' $n$ heffing gekies vir ons studie van $10 \mathrm{c} / \mathrm{m}^{3}$ water, wat deur myne verbruik word, omdat die waterowerhede reeds lankal oor 'n heffing van 10 sent in hul literatuur begin besin het (Van Heerden et al. 2007:112).

Eerstens is aanvaar dat bedrywe totaal ongevoelig (onelasties) vir veranderinge van ander ekonomiese aanwysers is, en dit word in kolom 4 van Tabel 2 weergegee. Met ander woorde, elastisiteit gelyk aan zero is gebruik. Daarna is die elastisiteit wat gedurende die eerste rondte van skattings bepaal is, gebruik, naamlik 0.32 vir steenkool, goud en ander mynboubedrywe, en 'n elastisiteit van 0.48 vir ru-olie, petroleum en gas. Vervolgens word die navorsingsresultate van die studie aangedui en bespreek.

\section{Empiriese resultate}

Die invloed wat belastingheffings op waterverbruik deur myne op Suid-Afrika se ekonomiese groeikoers, waterbesparing en algemene verbruik deur die armes sal hê, is in hierdie studie ondersoek, beide op die kort en lang termyn. Van Heerden et al. (2007:107) toon aan dat beperkinge op die industriële gebruik van water tot 'n beter toewysing van hulpbronne kan lei, met 'n gepaardgaande verhoging in algehele welvaart in die land. Vervolgens word daar eerstens aandag geskenk aan die scenario's op die kort termyn.

\section{Simulasies gerig op die kort termyn}

Ondervinding met algemene ewewigsanalise het geleer dat dit ten minste twee jaar duur vir impulse om volledig deur die land se ekonomiese stelsel te werk (Volkwyn \& Kleynhans, 2014:5). Vir die doel van hierdie studie is twee jaar daarom as "n kort termyn' aanvaar. Die verskillende veranderlikes is telkens in terme van veranderinge in owerheidsinkome uitgedruk. Die uitkomste van verskillende beleidscenario's kon gevolglik in terme van bykomende belastinginkome vergelyk word.

Die relevante veranderlikes wat 'n invloed op die verbruik van water, reële inkome en produksie in Suid-Afrika het, en die algemene vlak van verbruik deur die armes, word in Tabel 2 aangetoon (uitgedruk as persentasies). Dit stel die navorsers in staat om te bepaal wat die invloed van bykomende belasting op die onderskeie mynbousektore en die land as geheel behoort te wees.

Die resultate in Tabel 2 toon aan dat totale mynbouproduksie op die kort termyn (rye 1 tot 4 gesamentlik) sowat $0.0194 \%$ sal daal, indien 'n bykomende belasting op waterverbruik van 10 sent per kubieke meter gehef sal word. Die prys van mynbouprodukte sal terselfdertyd $0.0041 \%$ styg wat die land op hierdie gebied ekonomies minder mededingend sal maak, maar tog het die model daarop gewys dat indien die hele ekonomie in ag geneem word, soos wat algemene 
ewewigsmodellering doen, dan behoort uitvoere wel steeds met $0.01 \%$ toe te neem. Die prys van steenkool sal effens styg, wat die armes moontlik kan benadeel, maar die brandstofprys sal met $0.0021 \%$ daal. Hierdie syfers kan miskien gering lyk, maar onthou dat dit van toepassing is op die hele land se produksie en totale arbeidsmag, wat uiteindelik wel aansienlike getalle toon.

Saam met die daling in produksie deur myne sal indiensname gevolglik ook afneem. In totaal sal werksgeleenthede by myne op die kort termyn met $0.0331 \%$ daal. By steenkool en die petroleumbedryf sal dit egter effens toeneem. Reële produksie en totale inkome van alle landsburgers (BBP) sal wel effens daal, maar via indirek teruggevorderde inkome deur die owerheid balanseer. Myne se gemiddelde vraag na water sal met $1.7 \%$ afneem, wat die doel van die voorgestelde belasting is.

Tabel 2 toon aan dat 'n bykomende belastingheffing 'n negatiewe las op die myne sal plaas. Fullerton (1987:2) definieer die bykomende grenslas (BGL) as die land se reële inkome $(\mathrm{BBP})$ relatief tot die reële toename in owerheidsinkome. Die BGL is hier negatief, terwyl die besparing van water per eenheid groter is (ry 26) en die heel armste huishoudings bevoordeel word wat hul algemene verbruik betref (sien ry 27). Hierdie resultate is besonder positief, aangesien dit die land se totale inkome (BBP) minder benadeel en die armes bevoordeel.

Die invloed wat hierdie bykomende belasting op mynbouproduksie en pryse sal hê (rye 1-8) is uiteenlopend; sommige is positief en ander nie. Die meeste myne gebruik nie oormatig baie water tydens hul produksieprosesse nie, alhoewel Tabel 2 aantoon dat dit relatief gesproke is. Die gevolgtrekking is dat bykomende belasting nie ' $n$ baie groot impak op die produksie van myne sal hê nie en dit die prys van hul produkte nie noemenswaardig sal verhoog en hul mededingendheid benadeel nie.

\section{Terugvordering van inkome}

Die inkome wat die staatskas sal verkry op die heffing van 'n bykomende belasting op mynwater, sal geherkanaliseer word en kan moontlik selfs tot die daling van ander belastings lei (sien Tabel 2 se laaste kolom). Dié studie het die gevolge wat dit op die omgewing, die ekonomie en inkomegelykheid onder die landsburgers sal hê, ondersoek en bepaal wat die vooruitsigte van sodanige inkometerugvordering sal wees.

In die laaste kolom van Tabel 2 word die invloed van die dalende indirekte belastinglas aangetoon. Daar is gevind dat dit die inkomste van die owerheid met ongeveer

TABEL 2: Korttermynsimulasies: Resultate van die sleutelveranderlikes.

\begin{tabular}{|c|c|c|c|c|}
\hline \multirow[t]{2}{*}{ Rye } & \multirow[t]{2}{*}{ Sleutelveranderlikes } & \multicolumn{2}{|c|}{ Bykomende 10 c-belasting op myne } & \multirow{2}{*}{$\begin{array}{l}\text { Teruggevorderde } \\
\text { inkome ná 'n verlaging } \\
\text { van die indirekte } \\
\text { belastingkoers }\end{array}$} \\
\hline & & $\begin{array}{c}\text { Steenkool, goud, ander mynbou }=0.32 \\
\text { elastisiteit; } \\
\text { Ru-olie, petroleum en gas }=0.48 \text { elastisiteit }\end{array}$ & Verwysing: Alle elastisiteit $=0$ & \\
\hline 1 & $\% \Delta$ Produksie: Steenkool & 0.0004 & 0.0004 & -0.003 \\
\hline 2 & $\% \Delta$ Produksie: Goud & -0.0577 & -0.0586 & -0.003 \\
\hline 3 & $\% \Delta$ Produksie: Ru-olie, petroleum en gas & 0.0043 & 0.0044 & -0.0011 \\
\hline 4 & $\% \Delta$ Produksie: Ander mynbou & -0.0247 & -0.02504 & -0.0015 \\
\hline 6 & $\% \Delta$ Prys van goud & 0.0120 & 0.0122 & 0.0006 \\
\hline 7 & $\% \Delta$ Prys van ru-olie, petroleum en gas & -0.0021 & -0.0021 & 0.0016 \\
\hline 8 & $\% \Delta$ Prys van ander mynbou & 0.0058 & 0.0059 & -0.00003 \\
\hline 9 & $\% \Delta$ Indiensname: Steenkool & 0.0008 & 0.0008 & -0.0071 \\
\hline 10 & $\% \Delta$ Indiensname: Goud & -0.087 & -0.0883 & -0.004 \\
\hline 11 & $\% \Delta$ Indiensname: Ru-olie, petroleum en gas & 0.0115 & 0.0117 & -0.0024 \\
\hline 12 & $\% \Delta$ Indiensname: Ander mynbou & -0.0576 & -0.0585 & -0.0032 \\
\hline 14 & $\% \Delta$ Vraag na water: Goud & -1.5154 & 0 & 0 \\
\hline 15 & $\% \Delta$ Vraag na water: Ru-olie, petroleum en gas & -2.2395 & 0 & 0 \\
\hline 16 & $\% \Delta$ Vraag na water: Ander mynbou & -1.5154 & 0 & 0 \\
\hline 17 & $\% \Delta$ Totale uitvoer & 0.01 & 0.0104 & -0.0131 \\
\hline 18 & $\% \Delta$ Reële produksie (BBP) & -0.0009 & -0.0009 & 0.0008 \\
\hline 19 & $\Delta$ Reële produksie (BBP) & -6.7038 & -6.8072 & 5.6135 \\
\hline 20 & $\% \Delta$ Totale vraag na water & -0.0365 & 0.0013 & 0.0004 \\
\hline 21 & Inflasie op die armste huishoudings (VPI) & -0.0106 & -0.0108 & -0.0027 \\
\hline 22 & $\% \Delta$ Verbruik deur armstes & -0.00021 & -0.0002 & -0.0001 \\
\hline 23 & $\% \Delta$ Indiensname van ongeskooldes & -0.0056 & -0.0057 & 0.0037 \\
\hline 24 & $\Delta$ Reële owerheid & 40.6173 & 41.2424 & -40.6173 \\
\hline 25 & Bykomende grenslas $\dagger$ & -0.1651 & -0.1651 & -0.1382 \\
\hline 26 & Waterbesparingsmaatstaf $\dot{t}$ & -0.0009 & 0.00003 & -0.0000103 \\
\hline 27 & Maatstaf vir gelykheid§ & -0.000005 & -0.0000051 & 0.000002 \\
\hline
\end{tabular}

Bron: Skattings deur die outeurs

$\dagger$, Bykomende grenslas (Marginal Excess Burden): Verandering in reële BBP/Verandering in reële owerheidsinkome (ry 19/ry 24).

$\$ \%$ Verandering in totale vraag na water/Verandering in reële owerheidsinkome (ry 20/ry 24).

$\$, \%$ Verandering in die algemene verbruik deur die armstes/Verandering in reële owerheidsinkome (ry 22/ry 24). 
$40.6 \%$ sal verhoog (ry 24). Daar is gevolglik 'n groot vermenigvuldigingseffek ten gunste van die staat. Deur die loop van die jaar word hierdie fondse dus meer as een keer gebruik en telkens val 'n gedeelte na die owerheid toe in die vorm van belasting. Daar is met ander woorde eerstens 'n direkte effek wat gevolg word deur indirekte belastingheffings soos wat die veranderinge in die ekonomie deurwerk. Aanvanklik sal die direkte belasting op myne die land se totale inkome en produksie (BBP) met 6.7\% laat daal (ry 19), maar die indirekte belastingeffek van die teruggevorderde inkome deur die owerheid lei uiteindelik tot ' $n$ totale verhoging in almal se inkome (soos aangedui deur die positiewe BBP) van 5.6\% (ry 19).

\section{Simulasies gerig op die lang termyn}

'n Soortelyke skok van tien sent bykomende belasting per kubieke meter mynwater is in hierdie afdeling van die studie op die model toegepas om die uitwerking daarvan op die lang termyn te bestudeer. Die langtermynresultate word in Tabel 3 opgesom. Hier behoort daarop gelet te word dat die aannames rakende die produksiefaktore tussen die kort- en langtermynskattings verskil. Op die lang termyn kan faktore verander, terwyl kapitaalvoorraad byvoorbeeld op die kort termyn konstant is. Op die lang termyn kan kapitaalgoedere en -toerusting sodanig aangepas word dat dit die hoogste winste sal verseker, terwyl die betalingsbalans moontlik weer op die lang termyn konstant kan wees. Veranderings in die verskillende teikenveranderlikes word steeds as 'n persentasie uitgedruk.
In Tabel 3 word aangetoon dat die BGL op die lang termyn 'n negatiewe impak sal hê, ongeag die sensitiwiteit van die mark (elastisiteit). In elk geval lei dit tot 'n daling van 0.09\% in die BGL. Nasionale welvaart, produksie en inkome (die BBP) sal op die lang termyn wel effens daal (0.00056\%), maar weer gedeeltelik deur teruggevorder inkome van die staat herstel word.

Langtermynproduksie deur myne (rye 1-4) sal gemiddeld $0.06 \%$ afneem, terwyl produksie van steenkool, ruolie, petroleum en gas op die lang termyn sal toeneem, waarskynlik omdat hul pryse sal afneem. In totaal sal die prys van mynbouprodukte (rye 5-9) gemiddeld met $0.1111 \%$ styg wat die land se internasionale mededingendheid sal verlaag en uitvoere met $0.0027 \%$ sal laat daal. Die daling in produksie en uitvoer sal ook tot ' $n$ daling van $0.059 \%$ in werksgeleenthede by myne lei (rye 9-12), veral by goudmyne waar indiensname met $0.144 \%$ sal afneem. Die totale verbruik van water deur myne (rye 13-16) sal op die lang termyn met sowat $1.6964 \%$ daal, wat daarop dui dat die voorgestelde bykomende belasting op myne se verbruik van water, wel suksesvol behoort te wees.

'n Bykomende belasting op die verbruik van water deur myne sal egter op die lang termyn algehele verbruik deur die armes (nie net van water nie) met 0.00001\% verhoog. Dit is wel klein, maar vir die heel armstes is dit 'n noemenswaardige verhoging. Die prys van steenkool, petrol en gas sal ook op die lang termyn effens daal, wat veral die heel armes sal bevoordeel.

TABEL 3: Langtermynsimulasies: Resultate van die sleutelveranderlikes.

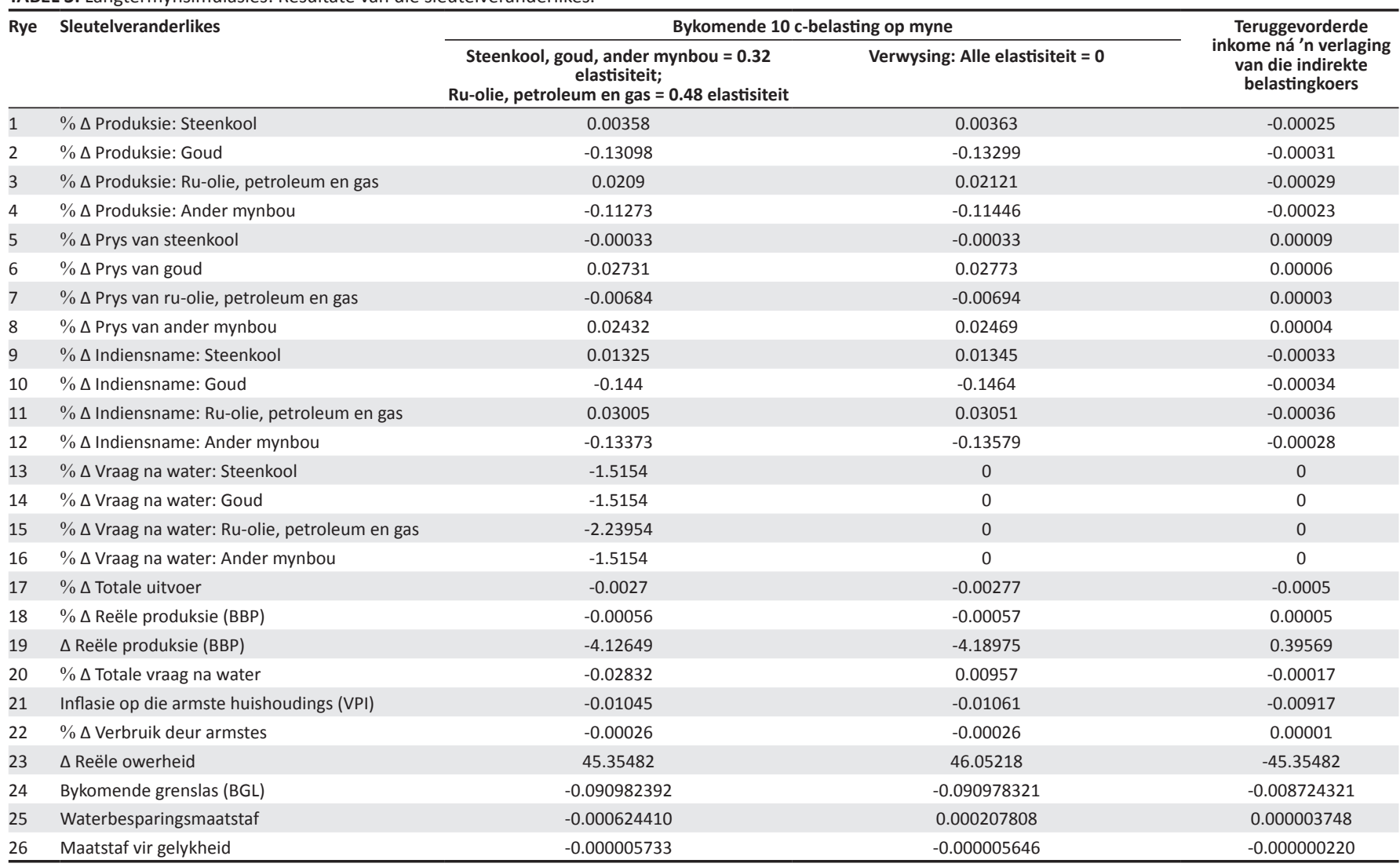

Bron: Skattings deur die outeurs 


\section{Samevatting en gevolgtrekkings}

Die dreinering van suur mynwater is ' $n$ groot bron van besoedeling in Suid-Afrika. Hierdie studie ondersoek maniere om die probleem die hoof te bied. Die owerheid kan in dié opsig nuwe beleid formuleer, bestaande beleid aanpas of ander moontlikhede ondersoek. Dit is egter nie maklik om na ' $n$ beter beleid oor te skakel nie. Die fout wat die meeste navorsers en besluitnemers dikwels maak, is om net op spesifieke nywerhede te konsentreer en op die kort termyn te fokus. Die langtermyngevolge wat dit moontlik vir al die rolspelers kan inhou en die invloed op die hele ekonomie, en al die onderskeie sektore, behoort in ag geneem te word.

Hierdie studie het in besonder op die uitwerking van 'n bykomende belastingheffing op die verbruik van water deur myne gefokus. Tydens die empiriese ondersoek daarvan is van ekonomies algemene ewewigsmodellering gebruik gemaak. Scenario's is gesimuleer wat beide die kort- en langtermyngevolge ondersoek het. Daar is in die besonder gekyk na wat die heffing van sodanige belasting op die ekonomie as geheel sou hê, sowel as op die verskillende mynboubedrywe, ander sektore en die welvaart van die armes.

Volgens die ekonomiese wet van vraag sal 'n bykomende belasting op water die verbruik daarvan laat daal. Dit sal ook lei tot besparings van water per rand, in die vorm van verhoogde belastinginkome vir die staatskas. Dit is egter noodsaaklik dat die meer verreikende invloed wat dit tot gevolg sal hê, in ag geneem word, veral ten opsigte van maatskaplike en ekonomiese kriteria. Indien 'n verhoging in staatsinkomste die enigste mikpunt van die owerheid is, kan dit miskien na 'n goeie voorstel lyk, maar die langtermyngevolge en die invloed op die ander sektore en verskillende inkomegroepe van huishoudings in die land behoort ook in ag geneem te word - soos wat in hierdie studie gedoen is.

Bykomende heffings op myne se waterverbruik sal addisionele fondse na die owerheid toe kanaliseer wat gebruik kan word vir die opruiming van besoedeling, en die suiwering en herwinning van water. Die owerheid kan moontlik selfs besluit om hierdie fondse op ander wyses tot die voordeel van die breër gemeenskap van Suid-Afrika te benut. Die doel waarvoor die bykomende belastings ingesamel word, kan egter nie uit die oog verloor word nie. Sodanige verhoogde staatsinkomste kan die owerheid ook in staat stel om normale belasting op die burgery te verminder; of dit kan dalk gebruik word om die huidige water-infrastruktuur te verbeter en op te gradeer.

Talle myne in Suid-Afrika ondervind die afgelope aantal jare reeds groot kostedruk op hul produksie en bedryfsuitgawes (Kleynhans 2012:683). Soos hul bestaande reserwes uitgedien raak, moet veral goudmyne afskaal en ander selfs toemaak (StatsSA 2012). Met bedryfskostes wat die hoogte inskiet, moet daar egter gewaak word dat belastings die myne nie so dramaties benadeel dat dit tot verdere werksverliese en ' $n$ daling in totale welvaart lei nie (Chamber of Mines 2012).

Die gevolgtrekking van hierdie studie is dat die instelling van bykomende belasting wel myne se waterverbruik sal verminder, met ' $n$ geringe negatiewe uitwerking op die res van die land. In die algemeen behoort dit tot ' $n$ verbetering van die land se waterbronne en verhoging in welvaart van die publiek te lei. Die praktiese gevolge van hoër waterheffings was wel in Duitsland suksesvol, maar nie in ander lande wat dit navolg nie (Boyd 2003). Suid-Afrika sal gevolglik die instelling van sodanige belasting baie deeglik moet oorweeg, beplan en vooraf oplossings vind vir die moontlike probleme wat dit kan oplewer, en seker maak dat dit wel verdere besoedeling van die land se waterbronne sal beperk.

\section{Erkenning}

Hiermee 'n spesiale woord van dank aan prof. Riaan Rossouw (Skool vir Ekonomie, Noordwes-Universiteit) vir sy hulp en advies tydens ons navorsing. Hy is 'n kundige op die gebied van algemene ewewigsmodellering in die Ekonomie en die toepassings daarvan. Sy raad en bystand was onontbeerlik.

\section{Mededingende belange}

Die outeurs verklaar hiermee dat hulle geen finansiële of persoonlike verbintenis het met enige party wat hulle voordelig of nadelig in die skryf van hierdie artikel kon beïnvloed nie.

\section{Outeursbydraes}

Die outeurs het min of meer gelyke bydrae gelewer. J.S. (Noordwes-Universiteit) het die meeste van die gedetailleerde empiriese analises, die literatuurstudie onderneem en dit genoteer. Sy het die oorspronklike konsep geformuleer en die aanvanklike data versamel. E.P.J.K. (Noordwes-Universiteit) het die artikel as geheel geskryf en die tegniese versorging gedoen. Hy was ook betrokke by die analise, literatuurstudie en die interpretasie van die empiriese resultate.

\section{Literatuurverwysings}

Adler, A., Claassen, M., Godfrey, L. \& Turton, R., 2007, 'Water, mining and waste: an historical and economic perspective on conflict management in South Africa', The Economics of Peace and Security Journal 2(2), 32-41. http://dx.doi.org/10.15355/ epsj.2.2.33

Boyd, J., 2003, Water pollution taxes: A good idea doomed to failure, Discussion Paper 03-20, Washington, DC.

Cameron, M.J. \& Naudé, W.A., 2008, 'Electricity supply shocks and economic development: The impact and policy implications of South Africa's power outages', paper delivered to UNU-WIDER Conference on Southern Engines of Global Growth: Africa and CIBS; Johannesburg, 05-06 September 2008.

Chamber of Mines in South Africa, 2012, 'Gold - value add \& data', Chamber of Mines of South Africa, Marshalltown, viewed 01 September 2014, from http://www. chamberofmines.org.za

Council for Scientific and Industrial Research (CSIR), 2001, 'Water resource accounts for South Africa', Report to Statistics South Africa and the Department of Environment Affairs and Tourism, Report number ENV-P-C 2001-050.

Department of Environmental Affairs and Tourism (DEAT), 1999, 'Background to the internal strategic perspective', Department of Water Affairs, Pretoria, viewed 01 September 2014, from http://www.dwaf.gov.za/Documents/Other/WMA/18/ BreedeISPOct04P2.pdf 
Department of Water Affairs and Forestry (DWARF), 1997, White paper on a National Water Policy for South Africa, Pretoria.

Department of Water Affairs and Forestry (DWARF), 1999, Water-use licensing: The policy and procedure for licensing stream flow reduction activities (Final edition), Pretoria.

Department of Water Affairs and Forestry (DWARF), 2008, A guide to the registration of water use: Under the National Water Act, (Act 36 of 1998), Pretoria.

Department of Water Affairs and Forestry (DWARF), 2009, Reporting directorate environment information and national state of the environment report, Pretoria.

Dervis, K. \& De Melo, J., 1985, General equilibrium models for development policy, Cambridge University Press, Cambridge.

Fullerton, D., 1987, 'The marginal excess burden of different capital tax instruments', Working Paper No. 2353, 1-3.

Hammel, A., White, C., Pfeiffer, S. \& Miller, D., 2000, 'Pre-colonial mining in southern Africa', The Journal of the South African Institute of Mining and Metallurgy, 4956.

Hobbs, P., 2010, A CSIR perspective on water in South Africa, Pretoria.

Horridge, M., 2003, 'ORANI-G: A generic single-country computable general equilibrium model', Australia.

Horridge, J.M., Parmenter, B.R. \& Pearson, K.R., 2000, 'ORANI-G: A general equilibrium model of the Australian economy', viewed 25 June 2013, from http:// monash.edu.au/policy/ftp/oranig/oranidoc.pdf

Janeke, A., 2012, 'Talle myne gaan voort sonder waterlisensie', Landbouweekblad, 78.

Kleynhans, E.P.J., 2012, 'Die effek van dalende goudmynproduksievlakke op indiensname in die Dr. Kenneth Kaunda-distriksmunisipaliteit', Tydskrif vir Geesteswetenskappe 52(4), 678-704.

Kleynhans, E.P.J. \& Kotzé, L., 2008, 'The effect of South African environmental legislation on the competitiveness of local industries: A critical analysis in the context of sustainability', The South African Journal of Environmental Law and Policy 15(2), 245-277.

Krog, A., 2000, Country of my skull: Guilt, sorrow, and the limits of forgiveness in the New South Africa, Broadway Books, New York.

Le Maitre, D.C., Versveld, D.B. \& Chapman, R.A., 2000, 'The impact of invading alien plants on surface water resources in South Africa: A preliminary assessment', Water SA 26(3), 397-408.

McDermott, S., 2012, 'Water watch increasingly urgent: Greening of the future', Mail and Guardian, 16-22.

Miller, R.E. \& Blair, P.D., 2009, Input-output analysis, foundations and extensions, Cambridge University Press, Cambridge. http://dx.doi.org/10.1017/ CBO9780511626982

Naicker, K., Cukrowka, E. \& McCarthy, T.S., 2003, 'Acid mine drainage from gold mining activity in Johannesburg, South Africa and environs', Environmental Pollution 122, 29-40. http://dx.doi.org/10.1016/S0269-7491(02)00281-6

Ochieng, G.M., Seanego, E.S. \& Nkwonta, O.I., 2010, 'Impacts of mining on wate resources in South Africa: A review', Scientific Research and Essay 5(22), 3351-3357.
Oelofse, S., 2008, 'Emerging issues paper: Mine water pollution', Department of Environmental Affairs and Tourism.

Plus Economics (PTY) LTD., 2010, 'The South African water crises: An economic impact study', (Unpublished).

PricewaterhouseCoopers (PWC), 2011, 'SA mine: Review of trends in the South African mining industry', viewed 01 September 2014, from http://www.pwc. co.za/en_ZA/za/assets/pdf/sa-mining-2012.pdf

Randwater, n.d., Water pollution, viewed 01 September 2014, from http://www. randwater.co.za/CorporateResponsibility/WWE/Pages/WaterPollution.aspx

Renzetti, S., 1992, 'Estimating the structure of industrial water demand: The case of Canadian manufacturing', Land Economics 64(4), n.p.

Smakhtin, V., Ashton, P.J., Batchelor, A., Meyer, R., Maree, J.P., Murray, M. et al., 2001, 'Unconventional water supply options in South Africa: Possible solutions or intractable problems?', Water International 26(3), 314-334. http://dx.doi. org/10.1080/02508060108686924

South Africa, 1994, Bill of Rights, Constitution of South Africa, Section 27(1)(b).

South Africa, 2007, Government Gazette, 296973, 16 March

StatsSA., 2002, 'Social Accounting Matrix for South Africa', Statistiek Suid-Afrika, Pretoria.

StatsSA., 2012, Tydreekse: 'Statistical release P2041 Mining: Production and Sales Jan, 1980 - Apr. 2012' Statistiek Suid-Afrika, Pretoria, viewed 01 September 2014, from http://www.statssa.gov.za

StatsSA., 2013, Databasis van Statistiek Suid-Afrika, Pretoria, besigtig 01 September 2014, by http://www.statssa.gov.za

Taylor, J., 2010, 'Acid Mine Drainage - is this the end to life in Gauteng?', viewed 12 June 2013, from http://www.earthlife.org.za/wordpress/wp-content/ uploads/2010/02/Acid-Mine-Drainage-the-end-of-life-in-Gauteng _.pdf

Tempelhoff, E., 2012, 'Hul kry permit vir water ná hulle al myn', Beeld, besigtig $15 \mathrm{Me}$ 2013, vanaf http://www.beeld.com/Suid-Afrika/Nuus/Hul-kry-permit-vir-waterna-hulle-al-myn-20120321

Tempelhoff, E. \& Van der Walt, S., 2012, 'Voos gemyn', Beeld, besigtig 15 Mei 2013, vanaf http://www.beeld.com/Suid-Africa/Nuus/Voos-gemyn-20120321

Trans-Caledon Tunnel Authority, 2007, TCTA: 'A new word for water' viewed 01 September 2014, from http://www.tcta.co.za/

Van Heerden, J.H., Blignaut, J.N. \& Horridge, M., 2007, 'Integrated water and economic modelling of the impacts of water market instruments on the South African Economy', Ecological Economics 66(2008), 105-116. http://dx.doi. African Economy', Ecological Econon
org/10.1016/j.ecolecon.2007.11.011

Veck, G.A. \& Bill, M.R., 2000, Estimation of the residential price elasticity of demand for water by means of a contingent valuation approach, Water Research Commission Report No: 790/1/00.

Volkwyn, B.J. \& Kleynhans, E.P.J., 2014, 'Die verskaffing van elektrisiteit deur Eskom Die impak van beurtkrag en hoër pryse op die Suid-Afrikaanse ekonomie', SuidAfrikaanse Tydskrif vir Natuurwetenskap en Tegnologie 33(1), Art. \#430, 11 pages, besigtig 01 September 2014, by http://dx doi.rg/10.4102/satnt 3331.430

Waternavorsingskommissie, 2004, South Africa, Water Research Commission, Pretoria. 